\section{Scientific journal}

\section{PHYSICAL AND MATHEMATICAL EDUCATION}

Has been issued since 2013.

Науковий журнал

ФІЗИКО-МАТЕМАТИЧНА ОСВІТА

Видається 32013.
ISSN 2413-158X (online)

ISSN 2413-1571 (print)

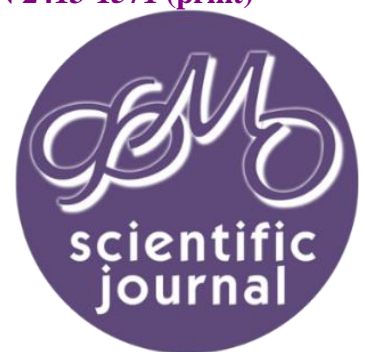

Жигайло О.О. Особливості застосування STEM-підходу в освітньому процесі початкової школи. Фізикоматематична освіта. 2021. Випуск 3(29). С. 58-62.

Zhigailo O. Features of the application of STEM approach in the educational process of primary school. Physical and Mathematical Education. 2021. Issue 3(29). P. 58-62.

DOI 10.31110/2413-1571-2021-029-3-009

УдК 373.091.313

о.о. Жигайло

Дрогобицький державний педагогічний університет імені Івана Франка, Україно okzhigajlo@ukr.net

ORCID: 0000-0001-8297-2951

\title{
ОСОБЛИВОСТІ ЗАСТОСУВАННЯ SТЕМ-ПІДХОДУ В ОСВІТНЬОМУ ПРОЦЕСІ ПОЧАТКОВОЇ ШКОЛИ
}

\begin{abstract}
АНОТАЦІЯ
Формулювання проблеми. Стрімкий розвиток усіх сфер людського життя, інтенсивне використання комп'ютерних технологій $і$ робототехніки в сучасному світі вносять необхідні специфіку навчально-виховного процесу на всіх ланках вітчизняних закладів загальної середньої освіти. Одним із перспективних напрямів її модернізації постає впровадження STЕМпідходу до освітнього процесу початкової школи з метою розвитку інтелектуальних здібностей та пізнавальнодослідницької діяльності учнів. Означена проблема сьогодні розроблена недостатньо $і$ задля свого вичерпного розв'язання передбачає отримання знань із різних галузей природничих наук, технологій програмування, а також напрямів, які охоплює STEM-освіта.

Матеріали і методи. Упродовж підготовки статті були використані такі методи дослідження: порівняльний аналіз теоретичних положень опрацьованої наукової та навчально-методичної літератури; спостереження за освітнім процесом вітчизняної початкової школи.

Результати. Для досягнення поставленої мети передовсім пропонується використання STEM-підходу в освітньому процесі початкової школи, впровадження навчальних модулів із застосуванням елементів аналізованого підходу задля комплексного розв'язання таких специфічних завдань, як розвиток інтелектуальних здібностей учнів упродовж пізнавально-дослідницької діяльності і залучення їх до науково-технічної творчості.

Висновки. Уведення основних компонентів STEM-освіти до навчальних програм сучасних вітчизняних з3СО дає змогу створити найоптимальніше середовище для виявлення та розвитку креативного потенціалу школярів. Застосування STEMтехнологій у початковій школі постає найбільш доцільним на елементарному пропедевтичному рівні. Увиразнено такі переваги STEM-підходу: а) активізує інтерес до математики та природознавства; б) мотивує до набуття відповідних знань у срері техніки, робототехніки, конструювання; в) сприяє розвитку творчих здібностей $i$ комунікативних навичок молодшого школяра, ранньому визначенню його особистісного потенціалу та майбутній орієнтації.
\end{abstract}

КЛЮчОВІ СЛОВА: STEM-освіта; початкова школа; урок математики; STEM - STEAM - STREAM-підходи; LEGO-конструювання.

\section{ВСТУП}

Постановка проблеми. Здійснивши аналіз науково-педагогічних та методичних джерел стосовно використання STEM-підходу у вітчизняній початковій школі, констатуємо відсутність єдиного визначення поняття «STEM-підхід» та виокремлення особливостей його впровадження. Фахівці наголошують, що «STEM-підхід інтегрує викладання природничих і математичних дисциплін за допомогою практичних наукових досліджень, технологічного та інженерного проектування, а також математичного аналізу й міждисциплінарних тем (Церковная, 2017)

Упровадження STEM-підходу передбачає цілий спектр новацій упродовж одного або кількох навчальних періодів або під час опанування навчальної програми. Крім того, їх можна реалізувати як на рівні одного навчального предмету, так і у позакласній або позашкільній діяльності загалом.

Аналіз актуальних досліджень. Особливості формування дослідницьких умінь в учнів початкових класів під час застосування STEM-підходу висвітлювалися багатьма зарубіжними і вітчизняними науковцями. Так, аналізові сутності феномену STEM-освіти присвячені дослідження С. Аверіна, Дж. Брейнера, К. Джонсона, К. Кохлера, Д. Крилова, В. Маркової, С. Харкнесса, А. Церковної, В. Чемекова. 
Трактування поняття «дослідницькі вміння», визначення їх структури простежуємо в наукових студіях Н.Л. Головізніна, А.Н. Подд'якова, Н.І. Поліхун, А.І. Савенкова, І.С. Чернецького, Е.А. Шашенкової та ін.

Психологічні аспекти терміна «уміння» увиразнені дослідниками Н.Д. Левітовим, Б.Ф. Ломовим, І.А. Сліпухіною, О.Є. Стрижак. Для Ю.К. Бабанського, Н.Г. Зюзькевич, Г.М. Коджаспірової, Ю.А. Коджаспірова та І.А. Церковної об'єктом вивчення стало розуміння змісту поняття “уміння» в педагогіці. Зі свого боку, вчені С.В. Зуєва, Н.А. Федотов та А.В. Хуторський виокремили структурні компоненти дослідницьких умінь. Класифікації загальнонавчальних, а також дослідницьких умінь укладено Н.В. Андреєвою, К.П. Кортневим, В.В. Марголіною, А.О. Татур, М.М. Шушаріною та ін. Серед досліджень останніх років, присвячених формуванню дослідницьких умінь у молодшому шкільному віці, вважаємо цікавими роботи Н.Р. Балик, А.П. Гладкової, Н.А. Семенової, Г.П. Шмигер.

Мета статті - дослідити проблему впровадження STEM-освіти в освітній процес вітчизняної початкової школи.

\section{МЕТОДИ ДОСЛІДЖЕННЯ}

Нами проаналізовано практичний досвід науковців та методистів щодо організації та проведення занять 3 використанням STEM-підходу в освітньому процесі початкової школи, а також опрацьовано наявну психолого-педагогічну та науково-методичну літературу з теми нашої розвідки. Загалом застосовано методи контент-аналізу, синтезу, порівняння, опису одержаних результатів дослідження й узагальнення.

\section{ТЕОРЕТИЧНІ ОСНОВИ ДОСЛІДЖЕННЯ}

Як зазначають H.P. Балик та Г.П. Шмигер «STEM-освіта - це програма навчання, яка готує учнів до успішного працевлаштування та передбачає розуміння наукових понять, формування технічно складних навичок із застосуванням знань у галузі інженерії, технології та математики» (Балик \& Шмигер, 2017).

Державним стандартом загальної середньої, позашкільної, дошкільної, вищої освіти, а також спеціалізованими стандартами STEM-освіти визначено їі структуру.

Фахівці виокремлюють три етапи впровадження STEM-освіти у школі, що включають інтеграцію традиційних навчальних предметів та занять інтегрованого курсу «я досліджую світ» на кожній із ланок:

- у початковій школі - це мотивація до навчання, зацікавлення молодших учнів та стимулювання їх до досліджень, створення найпростіших моделей і приладів;

- у середній школі - зміцнення інтересу дітей до природничо-математичних дисциплін; забезпечення засвоєння технічних знань, потрібних у подальшому житті людини; розуміння екологічного підходу до довкілля, мотивація до дослідницько-винахідницької діяльності;

- у старшій школі - вибір профільного навчання за допомогою STEM-підходу, освоєння наукової методології досліджень (Стрижак \& Сліпухіна, Поліхун, Чернецький, 2017).

Запровадження основних компонентів STEM-освіти уможливлює створення максимально сприятливих умов для виявлення обдарованих дітей ще у молодшому шкільному віці.

STEM - STEAM - STREAM-підходи, ґрунтовані на дослідженні як провідному типі навчальної діяльності, котре іноді набуває не строго наукового, а спонтанного й несподіваного характеру.

Таке навчання включає увиразнення розв'язання численних проблем, пошуки відповідей на питання, реалізацію певних процесів, складання проектів, що мають свої цілі, завдання і ролі. При цьому учні набувають статусу самостійних авторів, ініціаторів, лідерів чи членів команди, а відсутність традиційної теми уроку замінюється аналізом необхідних артефактів і проблемних ситуацій.

Задля з'ясування сутності STEM - STEAM - STREAM-підходів доцільно порівняти їх із традиційним вивченням шкільних предметів хоча б в одному з аспектів (наприклад, стосовно організації навчання і змісту навчальної діяльності).

Основною відмінністю STEAM-підходу $\epsilon$ його, так би мовити, суто прикладний, практичний характер: діти самостійно здобувають певні знання шляхом пріоритетного використання власних розумових та фізичних сил.

Загалом STEM-технології розвивають інтерес учнів до технічних навчальних дисциплін, удосконалюють навички критичного мислення, сприяють розв'язуванню нестандартних задач шляхом тестування і проведення різноманітних дослідів, активізують комунікативні навички школярів. Іншими словами, згадані технології дають змогу дітям підготуватися до дорослого життя, де вони часто стикатимуться з проблемними ситуаціями.

Фахівці акцентують, що ключовими питаннями в розбудові STEM-освіти є надійна цільова підтримка ефективної професійної підготовки STEM-педагогів; реалізація ініціатив, спрямованих на залучення й утримання талановитих STEMвикладачів; розроблення високоякісних стандартів у STEM-галузях; пріоритетний розвиток STEM орієнтованих проектів, програм і навчальних планів, які включають аудиторну й позашкільну навчальну діяльність, зокрема польові дослідження, літні наукові табори, експедиції, конкурси, турніри тощо. Науковцям необхідно активізувати дослідження компетентності школярів у проектній, навчально-дослідницькій та науково-дослідницькій діяльності як одного з результатів загальної середньої освіти (Церковная, 2017).

Як уже наголошувалося, впровадження STEM-підходу в основному передбачає командну роботу дітей, які більшу частину часу спільно досліджують якесь явище, розвивають свої вміння й навички налагоджувати діалог із друзями.

Сьогодні STEM-освіта постає своєрідною сполучною ланкою між освітнім процесом, кар'єрою і подальшим професійним ростом. Інноваційна освітня концепція уможливить на фаховому рівні підготовку дітей до технічного прогресу у світі.

Науковці 21 століття розглядають STEM як нову систему навчання, яка шляхом інтеграції інноваційних технологій сприяє всебічному розвитку особистості учнів та нового типу мислення в них. Навчання за STЕМ-моделлю суттєво відрізняється від традиційної системи шкільної освіти, оскільки передбачає розвиток не лише аналітичних навичок, а й творчих умінь учнів. Наприклад, на занятті інтегрованого курсу «Я досліджую світ» у 2 класі дітей ознайомлюємо за 
допомогою короткого фільму з певними явищами навколишнього середовища, використовуючи ігри або ігрові завдання, формуючи в учнів уявлення про живу і неживу природу.

Створюючи малюнки або виготовляючи певні вироби, діти спостерігають, пізнають об'єкти, тобто отримують знання дослідним шляхом. Вивчення пропонованого матеріалу виробляє навички самопідготовки учнів упродовж перегляду відео, прослуховування аудіо-записів, збору інформації на сайтах в інтернеті. Не менш важливим етапом $\epsilon$ перевірка рівня засвоєння теми, запис або зйомка відеоматеріалів про реальні об'єкти дослідження, предмети чи явища живої та неживої природи. Останній етап уроку за STEM-моделлю включає зйомку групового відео на 10 хв. Педагог може чітко визначити знання та обізнаність учнів із розглядуваної теми.

Під час STEM-навчання школярі розвивають навички самопідготовки, самостійного розв'язання численних проблеми. Спілкуючись між собою, діти обмінюються набутим досвідом, при створенні проектів охоче допомагають один одному.

STEAM-підхід $€$ орієнтує на розвиток дослідницьких навичок. За допомогою яких учні розумітимуть i пам'ятатимуть, а не зазубрюватимуть його.

Розробка уроків математики з використанням STEM-підходу спрямована на розвиток інтелектуальних здібностей школярів упродовж пізнавальної діяльності та залучення їх до наукової технічності. STEM-технології або їх окремі елементи також доцільно використовувати як у позаурочній діяльності в рамках основної освітньої програми початкової загальної освіти, так і в системі позашкільної освіти.

Сучасний світ ставить перед освітянами непрості завдання: підготувати дитину до самореалізації в суспільстві майбутнього, яка неможлива без наявності в особи розвинених інтелектуальних здібностей, що включають передусім уміння працювати з мінливої інформацією. Адже вдосконалення навичок отримувати, переробляти і практично використовувати отриману інформацію є підґрунтям STEM-освіти.

\section{РЕЗУЛЬТАТИ ДОСЛІДЖЕННЯ ТА ЇХ ОБГОВОРЕННЯ}

У результаті проведеного дослідження з'ясовано, що STEM-підхід уможливлює системне вивчення навколишнього середовища, розуміння його логічних закономірностей та ї взаємозв'язків, спонукає школярів до постійних пошуків i відкриттів, формує вміння бачити нове, незвичайне й цікаве у буденних звичних явищах довкілля.

Розвиток допитливості й пізнавальної активності дітей; необхідність самим визначати для себе цікаве завдання, обирати способи і шляхи чи алгоритм його розв'язання, вміння критично оцінювати результати - всі ці чинники формують у них інженерний стиль мислення, а колективна діяльність під час STEM-навчання виробляє навички командної роботи. Як бачимо, STEM-освіта забезпечує кардинально новий, більш високий рівень розвитку дитини, увиразнюючи перед нею майбутній вибір професії.

Нами розроблено п'ять навчальних модулів із використанням елементів STEM-підходу, ефективність яких перевірено експериментально. Стисло охарактеризуємо їх.

1. Освітній модуль «Експериментування з живою і неживою природою»:

- формування уявлень про навколишній світ упродовж дослідно-експериментальної діяльності;

- усвідомлення єдності всього живого під час наочно-чуттєвого сприйняття;

- формування екологічної свідомості.

2. Освітній модуль «LEGO - конструювання»:

- формування здатності до практично розумового експериментування, узагальнення, з'ясування причиновонаслідкових зв'язків, коментування процесу й результату власної діяльності;

- вироблення вміння групувати предмети;

- розвиток обізнаності в різних сферах життя;

- вільне володіння рідною мовою;

- формування вміння створювати нові образи, фантазувати, використовувати аналогію і синтез.

3. Освітній модуль «Математичний розвиток»

- забезпечення комплексного підходу до математичного розвитку молодших школярів (з урахуванням їхніх вікових та індивідуальних особливостей) за такими напрямами: величина, форма, простір, час, кількість і лічба.

4. Освітній модуль «Робототехніка»:

- розвиток логіки й алгоритмічного мислення;

- ознайомлення з основами програмування;

- розвиток здібностей до планування, моделювання;

- формування вмінь з обробки інформації;

- розвиток здатності до абстрагування й пошуку та знаходження закономірностей;

- вироблення вміння швидко розв'язувати практичні завдання;

- формування вмінь акцентування, схематизації, типізації;

- набуття знань та вмінь користуватися універсальними знаковими системами (символами);

- розвиток здібностей до самостійного оцінювання процесу й результатів власної діяльності.

5. Освітній модуль «Мультстудія «Я створюю світ навколо себе»:

- освоєння ІКТ (інформаційно-комунікаційних технологій) і цифрових технологій;

- ознайомлення з медійними технологіями;

- організація продуктивної діяльності на основі синтезу художньої й технічної творчості.

Як бачимо, кожен з описаних модулів, передбачаючи комплексне розв'язання специфічних завдань забезпечує реалізацію цілей STEM-освіти, а саме розвиток інтелектуальних здібностей учнів шляхом пізнавально-дослідницької діяльності, а також широке залучення їх до науково-технічної творчості. 
Відомо, що потік інформації сьогодні настільки величезний, а інструменти для розваг такі різноманітні, що недосвідченій дитині легко загубитися у величезному цифровому світі. Отже, вчителю необхідно обирати для навчання такі методи й засоби, які будуть зрозумілі дітям, розвиватимуть у них різноманітні компетенції. Таким ефективним навчальним інструментом може стати робототехнічних набір LEGO.

Конструктор LEGO дає змогу дітям, незалежно від їхніх інтелектуальних особливостей, успішно оволодівати необхідними знаннями. Наприклад, на уроці математики з його допомогою школярі наочно з'ясовують, що відрізок частина прямої, обмежена точками, яка має початок і кінець (вони показані цеглинками червоного кольору). А ось промінь має початок, але не має кінця.

Ще один приклад. Пряму лінію можна продовжити в обидві сторони (вчитель прикріплює цеглинки «точки»). Для першокласників стає зрозуміло, що пряма лінія - це безліч точок, розміщених упритул одна до одної. Діти запам'ятовують це наочно, будують пряму, з цеглинок LEGO (точок). Для демонстрації точок, що лежать на прямій і поза нею, можна використовувати інші засоби (наприклад, математичні планшети).

За допомогою лего-цеглинок, прикріплених до плати, доцільно наочно показати, що через одну точку можна провести багато прямих ліній, а через дві точки - провести тільки одну. Під час ознайомлення учнів із периметром та площею прямокутника чи квадрата ефективним засобом навчання залишається конструктор LEGO.

\section{ВИСНОВКИ ТА ПЕРСПЕКТИВИ ПОДАЛЬШОГО ДОСЛІДЖЕННЯ}

STEM-освіта стає все більш популярною серед сучасних педагогів. Однак хвилює мізерний теоретичний доробок у цій галузі, що й спонукало нас до написання пропонованої статті. Увиразнені переваги STEM-освіти дали підстави для висновку про те, що окреслений феномен є інноваційним підходом до освітнього процесу, що забезпечує ефективне формування дослідницьких умінь молодших школярів. Тому сьогодні застосування навчальних модулів із використання елементів STEM-підходу видається надзвичайно актуальним. STEM-освітяни покликані допомогти кожній дитині з'ясувати ії навчальні інтереси і мотивувати до їх розвитку, сприяючи особистісній самореалізації школяра. STЕМ-модель навчання має стати незамінним помічником педагога у розвитку дитячої інтуїції, їхнього вміння встановлювати причиновонаслідкові зв'язки, шукати закономірності явищ та подій тощо.

STEM-освіта, сприяючи розвитку творчої діяльності школярів, створює чудові умови для пошуку дитиною власного шляху розвитку з урахуванням ії інтересів та зацікавлень.

Перспективним вбачаємо подальше впровадження STEM-освіти на уроках математики у початковій школі та розробку конспектів уроків із використанням означеного підходу.

\section{Список використаних джерел}

1. Балик Н.Р., Шмигер Г.П. Підходи та особливості сучасної STЕМ-освіти. Фізико-математична освіта. 2017. № 2(12). С. 26-30.

2. Від ідеї до успіху. URL: http: //konkurs.tnpu.edu.ua/

3. Стрижак О.Є., Сліпухіна І.А., Поліхун Н.І., Чернецький І.С. STЕМ-освіта: ключові дефеніції. Інформаційні технології і засоби навчання. 2017. Т. 62. № 6. С. 16-33.

4. Церковная И.А. Возможности STЕМ-образования в развитии предпосылок инженерного мышления у детей дошкольного возраста. Фізико-математична освіта. 2017. № 2 (12). С. 156-160.

\section{References}

1. Balyk, N.R. \& Shmyher, H.P. (2017). Pidkhody ta osoblyvosti suchasnoi STEM-osvity [Approaches and features of modern STEM education] Fizyko-matematychna osvita - Physical and mathematical education. № 2(12), 26-30. [in Ukrainian]

2. Vid idei do uspikhu. URL: http: //konkurs.tnpu.edu.ua/ [in Ukrainian]

3. Stryzhak, O.le. \& Slipukhina, I.A. \& Polikhun, N.I. \& Chernetskyi, I.S. (2017). STEM-osvita: kliuchovi defenitsii [STEM education: key definitions] Informatsiini tekhnolohii i zasoby navchannia - Information technology and learning tools. Vol. 62. № 6, 1633. [in Ukrainian]

4. Tserkovnaia Y.A. Vozmozhnosti STEM-obrazovaniya $v$ razvitii predposyilok inzhenernogo myishleniya u detey doshkolnogo vozrasta [STEM-education in the development of prerequisites for engineering thinking in preschool children]. Fizykomatematychna osvita - Physics and mathematics education. 2017. № 2 (12). S. 156 - 160. [in Russian]

\section{FEATURES OF THE APPLICATION OF STEM APPROACH IN THE EDUCATIONAL PROCESS OF PRIMARY SCHOOL Oksana Zhigailo \\ Drohobych State Pedagogical University named after Ivan Franko, Ukraine}

Abstract.

Formulation of the problem. The rapid development of all spheres of human life, the intensive use of computer technologies and robot engineering in the modern world make the necessary specifics of the educational process at all levels of the national institutions of secondary education. The introduction of STEM approach into the educational process of primary school to develop intellectual abilities and cognitive and research activities of schoolchildren is one of the promising directions of the modernization of educational system. This problem is insufficiently developed, For its detailed solution it needs the acquirement of knowledge in various fields of science, programme technologies, as well as the directions of STEM education.

Materials and methods. The following research methods were used during the preparation of the article: comparative analysis of theoretical statements revealed in the studied scientific and educational literature; observation of the educational process of national primary school. 
Results. To achieve the goal it is proposed to use the STEM approach in the educational process of primary school, to introduce training modules using elements of the analyzed approach for the complex solution of such specific tasks as the development of intellectual abilities of schoolchildren during their cognitive and research activities and also their participation in scientific and technical creativity.

Conclusions. Introduction the main components of STEM education into the curricula of modern national institutions of secondary education enables to create the best environment for the discovering and development of schoolchildren's creative potential. The use of STEM technologies at primary school is the most expedient at the elementary, propedeutical level. The STEM approach has great advantages, namely, a) it intensifies the interest in mathematics and natural science; $b$ ) it motivates to gain knowledge in the field of technics, robot engineering, design; c) it promotes the development of primary schoolchildren's creative abilities and communication skills, and it furthers early identification of their personal potential and future orientation.

Key words: STEM education, primary school, Mathematics lesson, STEM - STEAM - STREAM approaches, LEGO design.

\section{(C)) BY-NC-SA}

This work is licensed under Creative Commons Attribution-NonCommercial-ShareAlike 4.0 International License. 